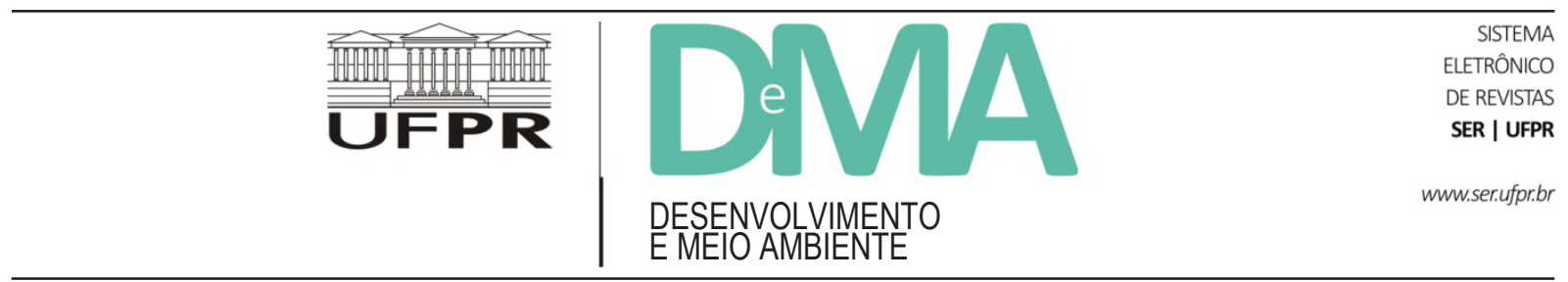

\title{
Bandidos na Serra do Mar? Conflitos, estratégias e usos múltiplos dos recursos naturais na Mata Atlântica de São Paulo
}

\section{Are There Bandits at Serra do Mar State Park? Conflicts, Strategies and Multiple Uses of Natural Resources in the Atlantic Forest of São Paulo}

\author{
Jorge CALVIMONTES ${ }^{1 *}$, Lúcia da Costa FERREIRA ${ }^{1}$ \\ ${ }^{1}$ Núcleo de Estudos e Pesquisas Ambientais (NEPAM), Universidade Estadual de Campinas (UNICAMP), Campinas, SP, Brasil. \\ *E-mail de contato: jorge.calvimontes@gmail.com
}

Artigo recebido em 22 de fevereiro de 2016, versão final aceita em 23 de maio de 2016.

RESUMO: O histórico da relação entre os moradores e os gestores do Núcleo Picinguaba do Parque Estadual da Serra do Mar (PESM), localizado no litoral norte do Estado de São Paulo, está caracterizado pelos conflitos relacionados aos direitos de permanência e de uso dos recursos naturais. Criado em 1977, o PESM permaneceu no papel até inícios dos anos 1980, quando começaram os primeiros contatos com os moradores. Estes moradores, trabalhadores do campo e pescadores, viram, então, deslegitimados seus direitos ao trabalho e à continuação de suas atividades produtivas e culturais. Desde então, passaram a ser considerados clandestinos, ilegais ou, segundo suas próprias palavras, "bandidos", devido a que a legislação proíbe a presença permanente de moradores neste tipo de áreas. O objetivo desta pesquisa foi analisar os conflitos, as estratégias e a organização dos diversos atores sociais vinculados ao Núcleo Picinguaba a respeito do uso dos recursos naturais e do acesso à terra e, finalmente, refletir se esta dinâmica influencia positivamente nos processos sociais associados à conservação da biodiversidade. Este conflito originou novas formas de organização no PESM: lideranças locais surgiram e se formaram associações comunitárias. Ao longo dos últimos anos, o diálogo entre gestão e moradores tem se intensificado e novos espaços de discussão e negociação, assim como novos atores com seus próprios interesses, têm aparecido. Três questões são transversais a este conflito: a questão da terra, a questão da identidade e a própria questão do uso e da conservação dos recursos naturais. Assim, os moradores têm se organizado em torno da luta pelo direito à terra, recorrendo para isso a estratégias identitárias e a categorias como populações tradicionais, quilombolas e caiçaras. Tudo isto em um contexto de uma UC de Proteção Integral, localizada em uma região não só altamente biodiversa, mas com um forte histórico de uso dos recursos naturais e de ocupação humana.

Palavras-chave: arenas; conflitos sociais; conservação da biodiversidade; Unidades de Conservação; usos múltiplos dos recursos naturais; populações tradicionais. 
ABSTRACT: The history of the relationship between inhabitants and managers of the Picinguaba Administrative Nucleus in the Serra do Mar State Park (SMSP) is characterized by conflicts related to the rights to permanence and to the use of natural resources. The SMPS is located in the northern coast of São Paulo State, the richest and more developed state of Brazil. Created in 1977, the park remained on paper until the beginning of the 1980s decade. At this moment, these inhabitants, rural workers and fishermen, were delegitimized and lost their rights to work and to continue their cultural and productive activities. Since then, the inhabitants were considered illegal or, on their own words, "bandits", due to the Brazilian law prohibiting the presence of inhabitants inside the Protected Areas with strictly protection. This research aims to analyze the conflicts, strategies and organization of the different social actors (inhabitants, managers, members of NGOs and researchers) related to the Picinguaba Nucleus, the use of natural resources and the access to land. All these actors have their own interests, perspectives, struggles and action strategies, and organize themselves around them in a very complex and multi-level arena. This conflict caused new forms of social organization in the SMSP: local leaders arose and communal associations that aim the struggle for the inhabitants rights were created. Three issues are transversal to this conflict and the strategies followed by the actors along the years: land issue, identity issue and use and conservation of natural resources issue. Thus, the inhabitants were organized around the struggle for their right to land, and using categories such as traditional people. All of this in a context with a Protected Area with strictly protection, located in a region not only with high biodiversity, but with a history of use of natural resources and human occupation.

Keywords: arenas; social conflicts; biodiversity conservation; Protected Areas; multiple uses of natural resources; traditional people.

\section{Introdução}

No Brasil, como no resto do mundo, tem persistido aquele velho dilema relacionado às unidades de conservação: Essas áreas devem ser grandes extensões de ecossistemas livres da presença humana ou devem incorporar o homem de forma que possa aproveitar os benefícios do uso sustentável dos recursos naturais? Apesar de ser muito difícil achar um espaço onde não existam pessoas, áreas protegidas que visam só ao uso indireto dos recursos têm sido criadas no Brasil. Desde então, milhares de trabalhadores do campo passaram a ser considerados clandestinos, ilegais, irregulares ou, segundo suas próprias palavras, "bandidos". Pescadores, agricultores e extrativistas das diversas regiões do país tiveram sua condição de trabalhador rural deslegitimada e foram ameaçados os seus modos de vida. Na pior das situações, estes moradores foram removidos de suas terras ou estão sob ameaça de sê-lo. Estabeleceu-se, desta forma, uma relação baseada em um "não", em negações vindas de todos os níveis do poder político, em proibições. Desde então, uma luta pelo direito à terra e ao trabalho começou. Mais recentemente, ideias sobre conservação, aliadas ao desenvolvimento sustentável e à melhoria da qualidade de vida da população local, foram postas em prática em diversas regiões do país com a criação das unidades de conservação de uso direto. Neste relativamente novo modelo, os moradores das áreas que se tornaram unidades de conservação devem adequar suas atividades econômicas às regras estabelecidas pelos órgãos de gestão, no melhor dos casos, de forma participativa. Estabeleceu-se, assim, uma relação baseada em um "como" - como realizar o aproveitamento dos recursos naturais e da terra, como manejá-los - e um diálogo, nem sempre fácil, teve de ser iniciado. Esses dois grandes tipos de Unidade de Conservação foram incluídos na Lei do Sistema Nacional de Unidades de Conservação (SNUC), promulgada no ano 2000. Dentro do primeiro grupo, 
estão as chamadas Unidades de Conservação de Proteção Integral, de uso indireto e que não permitem a presença permanente de moradores. De outro lado, estão as Unidades de Conservação de Uso Sustentável, cujo "objetivo básico é compatibilizar a conservação da natureza com o uso sustentável de parcela dos seus recursos naturais" (Brasil, 2000).

Especificamente nesta pesquisa, temos o Núcleo Picinguaba (NP) do Parque Estadual da Serra do Mar (PESM), o maior Parque do altamente ameaçado bioma da Mata Atlântica e localizado entre duas das maiores cidades da América do Sul, São Paulo e Rio de Janeiro, na região mais desenvolvida do país e onde cada vez mais empreendimentos econômicos de grande porte estão sendo implementados. Sem perder de vista as especificidades históricas, ambientais e políticas desta área, pode-se dizer que o conflito surgido pelo estabelecimento do PESM determina um ponto de inflexão na sua história. O que vem depois está diretamente influenciado por esse e outros acontecimentos e processos, como aqueles relacionados à ocupação da Serra do Mar. Os moradores venderam suas terras a preços muito baixos devido ao desconhecimento do valor delas no mercado (Ferreira, 1996). Este problema continua sendo uma das principais ameaças à conservação da Mata Atlântica na região. Deste processo histórico provêm os conflitos, muitas vezes ressignificados; as estratégias de luta, de ação ou de diálogo; a organização comunitária; as relações entre a gestão, os moradores e os outros atores envolvidos; os espaços de negociação; a ação coletiva. Tudo numa arena onde todos os atores, e não só os moradores, têm voz e negociam seus interesses a respeito do uso dos recursos naturais e da terra, quase sempre numa dinâmica de forte assimetria de poder.

O ponto de partida da análise desta pesquisa é o morador local. Quer dizer, a direção do raciocínio tem sido desde o morador para a arena dos atores. Dessa forma, seria possível entender a influência dessa arena sobre ele, assim como a influência e a opinião do morador sobre ela. É assim que surgem as perguntas da investigação: como, ao longo desses anos, os moradores têm se organizado como grupo social para enfrentar o conflito que apareceu após o estabelecimento de uma Unidade de Conservação de proteção integral onde eles moravam e trabalhavam? Quais foram as estratégias que estes moradores usaram, ao longo do tempo, para tentar alcançar seus objetivos relacionados ao direito à permanência e ao uso dos recursos naturais? Onde estão baseando suas decisões?

Segundo Coleman (1994), a ação social é um processo de negociação no qual os atores, que estão constrangidos por seus recursos existentes e que são conduzidos a maximizar seus interesses, interagem. Assim, as interações podem ser entendidas como processos de troca, caracterizados pela barganha e pela negociação. Não podemos perder de vista, entretanto, que, assim como os moradores, a gestão do PESM também teve de ter várias estratégias de ação ao longo dos anos. Essas estratégias também mudaram, e ainda mudam. A gestão e, especificamente, os gestores locais tiveram que enfrentar o dilema da presença humana dentro do Parque, ainda que a Lei não a permitisse, se adaptar às mudanças na política estadual de meio ambiente, assim como ao próprio processo histórico mundial a respeito da conservação da biodiversidade. Não foi objetivo direto e planejado do Governo do Estado de São Paulo, quando criou o PESM, atacar os moradores dessas áreas, pelo menos assim o esperamos. A privação de direitos e o prejuízo foram, isso sim, uma consequência de uma política na qual os moradores não tinham voz nem eram consideramos nas decisões. Eles eram invisíveis (Vianna, 2008). 
É neste contexto que esta pesquisa foi desenvolvida. Por um lado, a discussão sobre a presença ou não de moradores no interior de Unidades de Conservação e, por outro, o alto nível de vulnerabilidade do bioma onde o PESM está localizado. Como se relacionam esses dois pontos? O próprio título deste trabalho faz referência aos "bandidos na Serra do Mar" e se refere ao sentimento que os moradores de Picinguaba afirmam ter criado na sua relação com a história do Parque. Quem são essas pessoas? São de fato bandidos, como eles revelam que os outros atores os veem? Mas, será que os outros atores os veem realmente como bandidos? Em algum momento da história de Picinguaba pode ter sido isso o que acontecia, mas será que ainda é dessa forma? E como os outros atores na arena se relacionam entre si? Quais são suas posições?

O objetivo desta pesquisa é analisar os conflitos, as ações, as estratégias e a organização dos diversos atores sociais (moradores, gestores, membros de ONG, membros do poder público e pesquisadores) vinculados ao Núcleo Picinguaba do Parque Estadual da Serra do Mar, localizado ao norte do Município de Ubatuba, no Litoral Norte do Estado de São Paulo, a respeito do uso dos recursos naturais e do acesso à terra, e, finalmente, refletir se esta dinâmica influencia positivamente nos processos sociais associados à conservação da biodiversidade. Partimos da ideia de que todos esses atores têm seus próprios interesses, suas próprias perspectivas, motivações, lutas e estratégias de ação, e se organizam ao redor delas numa arena muito complexa e de múltiplos níveis.

\section{Arenas, conflitos e estratégias de ação}

Para o desenvolvimento desta pesquisa, foi usado o conceito de arena social, descrito por vários autores. Segundo Hannigan (2009), o termo arenas sociais é uma metáfora para descrever a organização política na qual os atores dirigem seus argumentos aos formuladores de políticas públicas, esperando influenciar o processo decisório. Para os autores da Mobilização de Recursos (McAdam et al., 1999), a afirmação básica da teoria da arena é que os grupos sociais em uma arena política tentam maximizar sua oportunidade de influenciar o resultado do processo de decisão coletiva por meio da mobilização de recursos. O resultado desta luta, entretanto, é determinado não só pelas ações individuais ou grupais, mas também pelas regras estruturais da arena e pelos efeitos de interação entre os grupos competidores. Esta teoria está baseada na suposição de que indivíduos e organizações só podem influenciar o processo político se tiverem suficientes recursos disponíveis para perseguir seus objetivos.

Para Renn (1993), a arena é um local simbólico porque não representa entidades geográficas nem sistemas organizacionais. Ela descreve as ações políticas de todos os atores sociais envolvidos em uma questão específica. O modelo da arena incorpora somente as ações de indivíduos ou grupos sociais que se destinam a influir nas decisões coletivas ou políticas. Como diz Ferreira (2012), a noção de arena pode ser perfeita para analisar os conflitos relacionados aos múltiplos usos dos recursos naturais, pois esses usos colocam em ação múltiplos agentes, múltiplos interesses e interpretações muitas vezes divergentes. Nesse sentido, continua a mesma autora, é possível tomar a noção de arena de Ostrom (1990), definida como situações nas quais um determinado tipo de ação coletiva ocorre, e cujos resultados nem sempre podem ser antecipados, sendo na maioria das vezes circunstanciais.

Entretanto, continua Ferreira (2012), Ostrom desconsidera a variável poder em suas análises 
sobre recursos de uso ou de apropriação comum e que, nessas situações, o conceito de arena social pode funcionar ora como uma metáfora (Renn e Hannigan), ora aplicado a situações de ação concretas (Ostrom). Geralmente, estas situações de ação concretas estão relacionadas a processos decisórios sobre os múltiplos usos dos recursos naturais, o acesso à terra e a definição de regras e termos, onde a negociação é constante e se desenvolve num contexto de forte assimetria de poder. Assim, Ferreira (2012) recomenda uma abordagem híbrida entre essas três ideias de arena para facilitar a análise de conflitos relacionados ao uso dos recursos naturais.

Uma característica importante da arena analisada nesta pesquisa é a situação de alta ameaça ambiental na qual se encontra o bioma Mata Atlântica e os esforços de conservação que precisam ser implementados nas escassas áreas que ainda permanecem conservadas. Algumas perguntas que surgem desta análise são: como devem ser implementados esses esforços? Sob quais paradigmas? Quais alternativas devem ser oferecidas a esses moradores? Que tipo de ator tem tido mais recursos de poder no momento das tomadas de decisão? Que tipos de uso dos recursos naturais vão ser priorizados e como esses usos vão se relacionar com a dinâmica econômica da região? Cada ator tentará influenciar as decisões nesta arena em função dos próprios interesses, quase sempre conflitantes, com os recursos que tenha disponíveis, usando as estratégias de ação apropriadas para cada situação e para cada nível da arena, tudo isto numa dinâmica de forte assimetria de poder.

É importante dizer aqui que a arena a ser analisada tem vários níveis onde as decisões são tomadas e onde cada ator pode desempenhar papéis diferentes, recorrer a estratégias específicas e tomar posicionamentos influenciados pelo nível em que a discussão está acontecendo (Figura 1). Cada nível da arena tem suas próprias características, suas próprias alianças, suas próprias estratégias e seus próprios processos de tomadas de decisão. Entretanto, os processos em níveis inferiores influenciam aqueles das arenas em níveis superiores, e vice-versa (Figura 2). Dessa forma, a agregação e a desagregação social (Gluckman, 1955; Simmel, 1983) em cada uma dessas arenas podem estar em função de diversas motivações e estratégias, fazendo com que atores que podem ser adversários numa arena localizada possam ser aliados em outra. A própria definição de cada indivíduo como ator na arena vai estar influenciada pela presença ou ausência dos outros atores, tudo isto em processos relacionais, de disputa ou de aliança, onde o conflito é central.

Segundo Gluckman (1955), os conflitos são parte da vida social e os costumes aparecem para exacerbá-los, mas, fazendo isso, os costumes também impedem que os conflitos destruam a ampla ordem social. Por outro lado, Touraine (1989) salienta a ideia de que o conflito não está mais associado a um setor considerado fundamental da atividade social, à infraestrutura produtiva da sociedade, ao trabalho em particular; ele está em toda a parte. A partir da discussão com esses autores, Ferreira (2005) é mais categórica quando diz que os conflitos são inerentes a qualquer sistema social, funcionando como propulsores de mudanças. Desta forma, o consenso seria apenas uma contingência, não havendo possibilidade de resolução definitiva de qualquer conflito. Assumir o conflito como uma parte inerente das relações sociais permite ampliar a observação para todas as possíveis interações (Ferreira, 2012).

No Núcleo Picinguaba, existe uma grande diversidade de atores com diversas motivações e objetivos que entram em conflito entre si. Ferreira (1996) e Almeida e Carneiro da Cunha (2001) concordam quando apontam que a biodiversidade e 

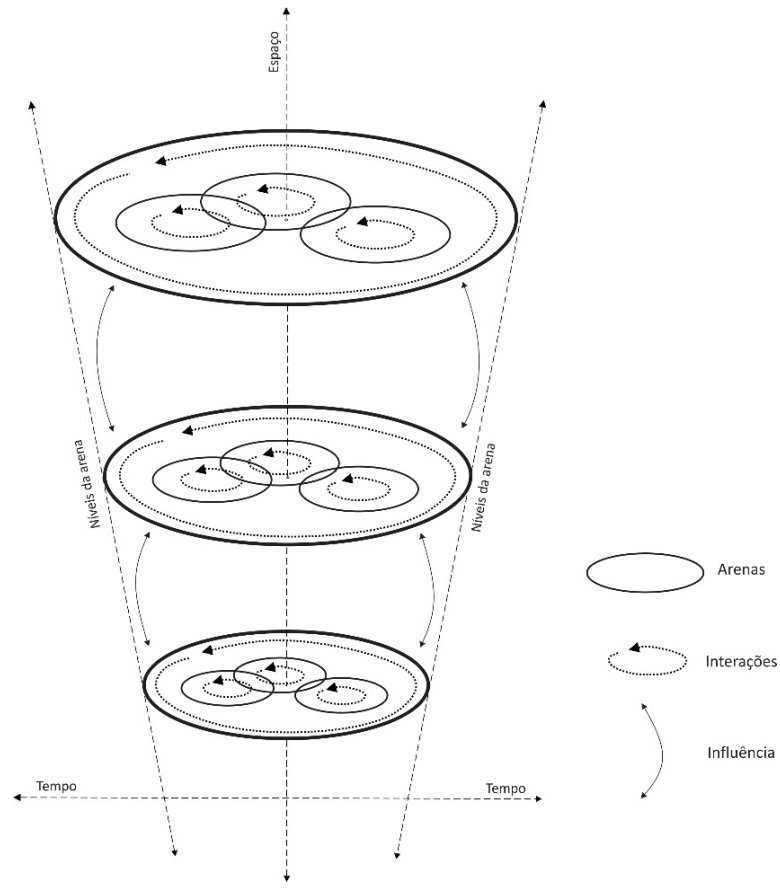

FIGURA 1 - Modelo conceitual de arena.

FONTE: Calvimontes (2013), modificado a partir de Ferreira et al. (2012).

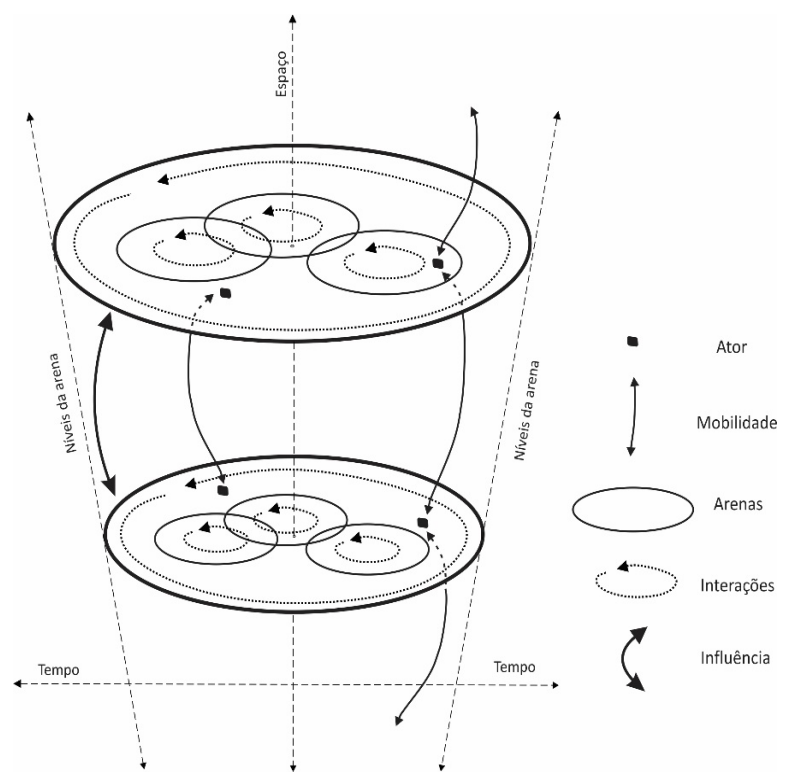

FIGURA 2 - Influência multinível dos atores na(s) arena(s). FONTE: Calvimontes (2013). o ambiente natural possuem significados e usos diferentes para fazendeiros e madeireiros que pensam na natureza como capital, para os prospectores de biodiversidade que pensam na natureza como tecnonatureza, para os conservacionistas profissionais e para os moradores ditos tradicionais. É por isso que a interdependência entre o que está em jogo e os atores é total (Touraine, 2006). As posições dos diversos atores sociais sobre o uso dos recursos naturais vão depender do que cada um deles tenha em jogo e do seu lugar na história. Desta forma, a compreensão sobre a posição dos outros atores nesse processo, assim como a possibilidade de negociação, não são tarefas simples.

\section{Identidades e Unidades de Conservação}

Segundo Vianna (2008), a partir de meados da década de 1980, no Brasil, os envolvidos na questão ambiental começaram a reconhecer certos grupos de moradores de áreas decretadas unidades de conservação como "populações tradicionais", expressão relativamente vaga e genérica, mas não totalmente desprovida de interesses. Desde então, o uso desta categoria tem se disseminado entre os diversos atores vinculados à conservação da biodiversidade e aos movimentos sociais rurais. Como categoria antropológica, essas populações podem se situar entre as chamadas sociedades rústicas. No meio ambientalista, "populações tradicionais" evoca os consagrados conceitos de sociedades tradicionais e sociedades complexas, adquirindo matiz utilitária, e, assim como no movimento social, passou a ter conotações política e ideológica (Vianna, 2008, p. 207).

O debate sobre a questão das populações tradicionais em unidades de conservação tem várias arestas. Pode-se pensar no próprio surgimento desta 
categoria e a crítica de alguns autores àquela "tradicionalidade" que lhe é atribuída, como se fosse uma característica que congelasse no tempo esses indivíduos e suas atividades produtivas. Ferreira (1996) diz que, dessa forma, se restringe o papel social desses grupos humanos ao de guardiães de remanescentes de uma história pretérita, tornando-os, assim, parte de um imaginário no qual está determinado o que eles deveriam ser e continuar sendo. Além disso, recoloca e aprofunda clivagens importantes entre os próprios grupos nativos, provocadas na maioria das vezes por disputas preexistentes pelo poder na comunidade (Ferreira, 1996; Ferreira et al., 2007).

Segundo Carneiro da Cunha e Almeida (2000), a categoria "populações tradicionais" está relacionada ao uso de técnicas ambientais de baixo impacto e a formas equitativas de organização social e de representação. Por outro lado, Esterci \& Schweickardt (2010) indicam que o processo de reconhecimento e legitimação da permanência de uma população humana em ambiente a ser conservado implica sempre alguma forma de enquadramento. Nesse mesmo sentido, Simões (2010) diz que os gestores e elaboradores de políticas públicas têm praticado constantemente o exercício de classificação de residentes de UCs em grupos tradicionais e têm gerado políticas diferenciadas de gestão dos mesmos.

Pode-se pensar, então, no uso da categoria "população tradicional" (caiçaras ${ }^{1}$ e/ou quilombo- $\operatorname{las}^{2}$ ) como estratégia política para enfrentar os conflitos relacionados ao uso dos recursos e ao acesso à terra ${ }^{3}$. Adicionalmente, deve-se lidar com os que duvidam que possa existir uma área plenamente conservada mantendo pessoas no seu interior; e com os que têm a visão oposta, de que os moradores locais "tradicionais" teriam a capacidade inata de conservação dos recursos naturais Nesse sentido, Vianna (2008) indica que a origem, no Brasil, da incorporação da discussão sobre a importância do papel de algumas populações na conservação da natureza, numa tentativa de aliar a conservação da biodiversidade à diversidade cultural, deve ser entendida sob duas perspectivas históricas. A primeira incorpora as populações ao discurso conservacionista (devido a que aqueles grupos teriam características "ecológicas" que poderiam ser "aproveitadas", inclusive nas UCs de proteção integral); e, a segunda, pelo contrário, incorpora o discurso conservacionista ao movimento social, fortalecendo as lutas para garantia de seu território e de acesso aos recursos naturais.

Por outro lado, e como se pretende destacar neste trabalho, o uso desta categoria pode ser feito pelos próprios moradores das áreas sob regime especial de proteção ou pelos atores relacionados à sua gestão como um instrumento relacionado às estratégias que cada um tem para lidar com o conflito. Em outras palavras, o uso e a apropriação do termo "população tradicional" faz parte de um processo histórico e político, e sua utilização pode variar muito

\footnotetext{
1 Os caiçaras são descritos como produto da miscigenação entre indígenas, negros e europeus, principalmente portugueses. Essa cultura se desenvolveu principalmente nas regiões litorâneas dos Estados de Rio de Janeiro, São Paulo e Santa Catarina (Diegues \& Arruda, 2001).

2 Os quilombolas são descendentes dos escravos negros que sobrevivem em enclaves comunitários, muitas vezes antigas fazendas deixadas pelos antigos grandes proprietários. Apesar de existirem, sobretudo após a escravatura, no fim do século passado, sua visibilidade social é recente, fruto da luta pela terra, da qual, em geral, não possuem escritura. A Constituição de 1988 garantiu seu direito sobre a terra da qual vivem, em geral de atividades vinculadas à pequena agricultura, artesanato, extrativismo e pesca, segundo as várias regiões em que se situam (Diegues et al., 2000).

3 Segundo Boyer (2015), pode-se constatar que optar por uma categoria classificatória, uma dentre um amplo leque de possibilidades, está diretamente relacionado ao regime político do Brasil atual. Esta definição eminentemente política da identidade põe em valor a capacidade das populações para recobrar a iniciativa.
} 
em função do ator que o utiliza ${ }^{4}$. Estes assuntos já foram discutidos amplamente e desde diversas perspectivas por muitos autores, como Almeida (1995), Ferreira (1996; 2005), Arruda (1999), Colchester (2000), Castro (2000), Diegues (2000; 2001), Carneiro da Cunha e Almeida (2000), Adams (2000), Almeida e Carneiro da Cunha (2001), Ferreira et al. (2001), Little (2002), Ferreira et al. (2007), Castro et al. (2008), Vianna (2008), Barretto Filho (2009), Carneiro da Cunha (2009), Mendes e Ferreira (2009), Esterci e Schweickardt (2010), Simões (2010), Mendes (2011), Boyer (2015), dentre outros. Sendo assim, talvez tenha chegado o momento de colocar o foco de atenção em outros assuntos que, ainda que estejam vinculados com a questão identitária, possam contribuir a um avanço em relação ao conflito sobre a presença humana em Unidades de Conservação e a participação dos moradores na sua gestão.

Nesse sentido, se reforça a ideia de que a questão identitária, a questão da terra e a questão do uso e conservação dos recursos naturais se inter-relacionam fortemente e são os eixos do conflito e das estratégias dos atores relacionados às Unidades de Conservação. As questões da identidade como "populações tradicionais" e seu uso político estão intimamente relacionadas com a luta pelo direito à permanência, pelo acesso aos recursos naturais e, em última instância, pela propriedade da terra. Identidade e território são duas faces da mesma moeda (Castro, 2000; Jolivet \& Léna, 2000; Little, 2002) no conflito pelos direitos dos moradores nas diversas regiões do país onde a conservação da biodiversidade é necessária e de interesse nacional.

\section{Procedimentos de pesquisa}

Desde fevereiro de 2010 até junho de 2012, após um período de reconhecimento da área, foram realizadas 57 entrevistas abertas com lideranças das quatro comunidades localizadas no interior do NP (Sertão de Ubatumirim, Vila de Picinguaba, Sertão da Fazenda e Cambury $^{5}$ ), com gestores locais e com membros da Fundação Florestal do Estado de São Paulo, com pesquisadores atuantes na região, com dirigentes de ONGs ambientalistas e com membros do poder público do Município de Ubatuba. Os pontos tratados nestas entrevistas estavam relacionados à história do estabelecimento do PESM e da relação da gestão com a população local; às atividades econômicas realizadas pelos moradores locais; à organização comunitária e seu histórico de formação e ação; às relações entre a população local, a pesquisa, a gestão, as ONGs e o poder público local; aos espaços onde estas relações acontecem; às estratégias comunitárias e de gestão para fazer frente ao conflito existente pelo acesso à terra e ao uso dos recursos naturais e às estratégias de ação de cada um destes atores.

\section{Relações acidentadas, conflitos transformadores e organização dinâmica}

A relação entre gestores e moradores do Núcleo Picinguaba foi, e ainda é, acidentada. É possível constatar, pelas vozes dos mesmos atores, que a criação do Parque e sua posterior implementação

\footnotetext{
4 Como parte deste processo, o Governo Federal promulgou o Decreto n ${ }^{\circ} 6.040$, de 7 de fevereiro de 2007, que define os Povos e Comunidades Tradicionais como "grupos culturalmente diferenciados e que se reconhecem como tais, que possuem formas próprias de organização social, que ocupam e usam territórios e recursos naturais como condição para sua reprodução cultural, social, religiosa, ancestral e econômica, utilizando conhecimentos, inovações e práticas gerados e transmitidos pela tradição" (Brasil, 2007); e os Territórios Tradicionais como "os espaços necessários à reprodução cultural, social e econômica dos povos e comunidades tradicionais, sejam eles utilizados de forma permanente ou temporária [...]" (Brasil, 2007).

5 As duas últimas são Territórios Quilombolas reconhecidos.
} 
significaram um ponto de inflexão na história da região e na vida desses grupos sociais. A construção da Rodovia BR-101 ${ }^{6}$ também é parte desse mesmo processo. As mudanças que a "chegada do Parque" trouxe consigo foram relacionadas principalmente à substituição da condição de trabalhador por uma outra que reduziu os moradores a meros moradores ilegais, clandestinos e "bandidos", e ocasionaram uma revolução na sua dinâmica social e na sua organização. A luta pelos direitos que eles caracterizam como violados foi o motor dessa revolução. O conflito surgido a partir da criação do Parque foi, e ainda é, o catalisador da mudança. Novos tipos de relações sociais surgiram, novos atores entraram em ação e o morador da região não esteve mais sozinho, ou quase sozinho, nos processos de tomadas de decisão a respeito do uso dos recursos naturais.

Os outros atores da arena (os gestores, os pesquisadores, as ONGs, os turistas) começaram, então, a ter estratégias e a exigir que fossem implantados os tipos de uso dos recursos naturais que cada um deles considerava como prioritários. Estes tipos de uso dos recursos podiam incluir, inclusive, o não uso. Adicionalmente, a assimetria de poder entre estes diversos atores é uma característica da arena, onde, em diversos níveis, se discute o futuro desta região altamente ameaçada, mas com um histórico de uso dos recursos naturais muito antigo e onde ainda moram grupos sociais que precisam desses recursos para sobreviver.

Uma liderança da região de Picinguaba relatou que, no passado, alguns encontros entre a gestão do Parque e os moradores foram violentos. Isto contribuiu para compreender a influência desses fatos na ação e na posterior organização social local. Os acontecimentos narrados por esta liderança não são só a origem da sua luta, mas constituem a definição do seu adversário e a guia para sua posterior conduta coletiva organizada (Touraine, 2006). Segundo esta liderança, a partir do momento em que teve sua casa derrubada pela fiscalização do Parque, começou "toda uma luta" porque tinha se tornado "uma bandida", enquanto "o pessoal do Parque" era visto e se sentia como "os poderosos". Ela decidiu que, no confronto, estava contra eles, contra o Parque. Da mesma forma, a primeira presidenta da Associação do Bairro de uma das comunidades disse: "Aqui o povo é um trabalhador bandido. Trabalha, mas tem que ficar olhando se a viatura não vem pra me levar [...]. Ai, fica sem a terra, sem dinheiro e sem casa para morar". Sobre a fiscalização, um morador disse: "Eles vêm te multar por uma coisa que você já estava fazendo, estar na roça. A dignidade de uma pessoa dessas aonde vai?’. Esta é a base sobre a qual foi construída a relação entre a gestão e os moradores.

A ocupação da Serra do Mar tinha trazido conflitos referentes à venda de terra, à especulação imobiliária e ao deslocamento de pessoas, mas, desta vez, era o próprio Estado que tirava a condição de trabalhador e tornava ilegítima e ilegal a presença dos moradores nesses territórios. Devido ao grau de ameaça da Mata Atlântica, de um modo geral, e da Serra do Mar, em particular, que a constitui como uma parcela importante do pouco que se mantém em pé, o confronto entre o Estado e os moradores é muito forte na região. Pode até parecer contraditório desde certo ponto de vista porque, por um lado, Picinguaba é uma das áreas de Mata Atlântica mais conservadas (IFSP, 2006), mas, por outro, não é possível ignorar o histórico do uso dos recursos naturais por parte dos seus mora-

\footnotetext{
6 Esta rodovia, conhecida também como Rio-Santos, foi construída entre 1974 e 1975 e atravessa o PESM no sentido norte-sul. A própria criação do PESM está relacionada a este empreendimento. Ver detalhes em Ferreira (1996), Simões (2010), Calvimontes (2013), dentre outros.
} 
dores. Esses moradores reivindicam a conservação da área às suas práticas e às dos seus antepassados, mas o Estado, devido à situação crítica do bioma e às grandes ameaças que enfrenta, restringe os tipos de uso desses mesmos moradores.

Então, a questão da terra, seu valor no mercado, a migração à região de Picinguaba (catalisada pela abertura da BR-101) e os métodos que utilizaram os que chegaram de fora para obter as terras ocasionaram grandes mudanças sociais e conflitos que perduram até hoje. Uma liderança local disse que "o pessoal antigamente não dava valor à terra". "Teve gente que trocou [sua terra] por cavalo, por espingarda. Porque não tinha ideia do valor", reforçou outro morador. Desde então, o conflito entre "os turistas", "os de fora", e a população local permanece e se transforma continuamente.

Por outro lado, não se pode assumir que sempre estamos nos referindo a dois bandos: por um lado a gestão, "o Parque", e por outro, os moradores (originários) e seus interesses contraditórios e de naturezas diferentes. O posicionamento dos atores pode mudar em função do nível (desde o comunitário até o estadual) e do tema que se discute. As mesmas lideranças locais que se referem ao Parque como o mais forte dos causadores de seus problemas podem ter uma opinião que pareça contraditória em outras circunstâncias. A presidenta de uma associação de moradores manifestou que, apesar de todos os problemas, "eu ainda prefiro o Parque". "Eu também", confirmou o pai dela, antigo morador da comunidade. Eles acham que a presença do Parque tem conseguido, de alguma forma, proteger a comunidade da "ameaça das pessoas de fora". Eles têm sido testemunhas do acontecido em outros locais sem proteção legal na mesma região: perda de floresta; forte ocupação de pessoas de fora em detrimento dos locais, que passaram a ter que subir as encostas dos morros ao invés de habitar as regiões costeiras (muitas das quais hoje são áreas de risco); dentre outras consequências.

Desta forma, a relação entre os moradores ditos tradicionais e "os de fora" também é complexa. Por um lado, consideram que são os moradores originários os que têm direitos sobre o território e o uso dos recursos e se queixam sobre a forma como "os de fora" ocuparam e continuam ocupando a terra. Uma liderança local disse: "Os turistas não querem ajudar nós. Eles querem que a gente vá embora [...] porque nós somos lixo pra eles [...]. Que a gente tem que trabalhar pra eles e acabou". Por outro lado, a partir da chegada dos "de fora", houve novas possibilidades de trabalho para os moradores originários: "Gerou serviço pra algumas pessoas, porque o cara comprou, fez uma casa e pega uma pessoa para tomar conta". Nessas circunstâncias, os moradores originários e os "de fora" podem ter diversas estratégias de aliança ou de confronto em função do nível da arena. Em determinadas oportunidades, eles podem agir juntos, em contraposição à gestão, e, em outras, separadamente.

O posicionamento da gestão sobre quem tem a permissão para participar da negociação e quem é excluído dela, baseado na categoria "população tradicional", cria uma brecha entre um e outro tipo de morador que, em alguns casos, podia não existir antes. Ou, também, pode ressignificar essas brechas e os conflitos intracomunitários, dando-lhes outras características (Campos, 2006). Ser considerado como "morador tradicional" pela gestão e por outros atores outorga maior capacidade e poder de negociação. Uma liderança disse a respeito deste assunto: "Houve situações de misturar quem é tradicional e quem não é. E virou um embate interno no bairro seríssimo que ocasionou, inclusive hoje, uma completa desfragmentação democrática no bairro". Entretanto, uma liderança se referiu ao 
tempo que levava morando na região uma pessoa que considerava "de fora": "uns 50 anos".

O conflito originado pelo estabelecimento do PESM foi o catalisador para o aparecimento de novas formas de organização social na região e para a modificação daquela já existente. Lideranças surgiram e formaram-se associações comunitárias que tinham por objetivo a luta por direitos. Uma das antigas lideranças da região disse: " $A$ associação começou pelo Parque, porque [a gente soube que] já foi feita uma lei. [...] Aí foi feita a associação". A organização da comunidade e sua integração em um grupo coeso é um fator muito levado em consideração pelas suas lideranças. Uma jovem liderança da comunidade Sertão da Fazenda reconheceu que "é importante a comunidade estar organizada. $O$ que falta pra gente é isso, porque agora a gente tem uma força maior e a gente tem que agarrar isso e correr atrás".

Essa organização tem propiciado, nas lideranças em particular, mas também em todos os moradores, uma maior circulação de informações sobre seus próprios direitos e a possibilidade de articular, junto a seus aliados, novas estratégias de ação de acordo com cada momento do processo. Nesse sentido, uma liderança ressaltou que "na hora da necessidade, a comunidade se une. Para defender os direitos, se unem", apesar dos conflitos internos e dos desacordos entre grupos intracomunitários. Como disse Touraine (1988), uma população excluída exprime a sua dor e a sua cólera de maneira comunitária, erguendo barricadas e acendendo fogueiras que mostram mais a sua resistência à entrada dos elementos hostis do que a sua vontade de atacar os centros de poder. Sobre o surgimento de lideranças nas comunidades do NP, um membro de uma ONG local disse que se "fortaleceram as lideranças a partir da interlocução com o Parque que começou a ter". Um pesquisador que trabalha na região também se referiu à organização das comunidades: "[As comunidades] antes eram bastante desorganizadas. Agora melhorou muito com crises grandes que teve, e resultou numa reorganização". Da mesma forma, um membro da gestão do Parque disse: "A comunidade começou passar num processo de mudança: 'temos que nós pôr de acordo para as coisas que vamos levar ao Parque'. [...] Você via a mudança dentro da comunidade".

Ao longo de todo este tempo, as lideranças comunitárias tiveram maior acesso à informação e, com isso, a mais ferramentas de luta, negociação e diálogo, assim como a maiores espaços para usá-las. Nesse sentido, se pode dizer que a assimetria de poder que existe atualmente entre os diversos atores, como entre moradores e gestores, é menor do que foi nos primeiros anos deste processo. A partir das relações entre os diversos atores, existiu um aprendizado, uma transformação. E isto não só aconteceu com os moradores: os gestores, os pesquisadores e os membros das ONGs atuantes na região também têm aprendido, ao longo dos anos, a negociar, escutar e compartilhar espaços com os outros atores. A questão identitária tem um papel central neste processo.

\section{Discurso da identidade como arma de luta e as estratégias possíveis de ação}

Os moradores do Núcleo Picinguaba organizaram-se (e ainda se organizam) em torno da luta pelo direito à permanência, o direito à terra, recorrendo para isso a estratégias identitárias e a categorias como populações tradicionais, quilombolas e caiçaras. É provável que, devido à pouca flexibilidade das normas relacionadas às dimensões humanas nas Unidades de Conservação de Proteção Integral, onde questões relacionadas aos direitos à 
propriedade da terra, ao trabalho e à permanência nos territórios não ofereceram os recursos de poder necessários para a negociação, os moradores originários tenham tido que utilizar uma questão anterior e mais básica para lutar e reivindicar seus direitos: a identidade. A bandeira da "população tradicional" torna-se, então, arma de luta.

O uso político das categorias jurídicas como população tradicional (Simões, 2010), caiçaras e quilombolas é evidente no Núcleo Picinguaba. Quando consultada se a procura pelo reconhecimento como quilombolas tinha uma relação com os conflitos entre a comunidade e o Parque, uma liderança de um dos quilombos disse: "É, a comunidade se sentiu tão oprimida, tão pisada, que tinha que procurar uma solução. Tinha que fazer alguma coisa para sobreviver, e sendo quilombo, foi uma porta que se abriu". Sobre as mudanças que esperava após o reconhecimento do Quilombo, disse: "Depois que estiver reconhecido como Quilombo, [...] o que acaba é a manipulação".

Independência, uma esperada emancipação das "pessoas de fora", dos políticos, da gestão do Parque, poder decidir quais recursos usar e como usá-los, é o que deseja esta liderança que, por sua vez, representa o desejo de todos os moradores. Esta busca de autonomia por parte dos moradores de Picinguaba está intimamente relacionada à estratégia identitária. Isto parece estar claro também para a gestão do Parque. A gestora do PESM sob cuja gestão foram implementadas as Zonas de Ocupação Temporária (ZOT) e as Zonas Histórico-Culturais Antropológicas (ZHCAn), tipo de ordenamento do território baseado no "estatuto jurídico de tradicionais" dos moradores (Simões, 2010), disse que "a questão do quilombo surgiu na região como uma necessidade, uma perspectiva jurídica para garantir a permanência na terra, e [...] então, a autonomia total que eles imaginam. Com certeza, o quilombo está ligadíssimo a essa situação".

Segundo esta gestora, a estratégia identitária está relacionada à autonomia e ao direito à terra. Sendo assim, a comunidade do Sertão da Fazenda teria optado por achar que a proposta da gestão do Parque, relacionada ao ordenamento do território segundo o plano de manejo, era um procedimento repressor, e que os privaria dos direitos pelos que lutavam. A respeito disso, um pesquisador com grande conhecimento da área disse: " $A$ Casa $d a$ Farinha [Sertão da Fazenda] talvez foi um dos primeiros lugares que eu ouvi uma posição, por parte dos moradores, de quem era turista e quem era de fato morador". A questão identitária, no sentido da diferenciação entre os "do lugar" e os "turistas", está presente desde cedo nas estratégias dos moradores de Picinguaba.

Da mesma forma, ainda que sem tanta força legal, a identidade caiçara está presente no discurso reivindicatório das comunidades que não têm a possibilidade de recorrer ao Quilombo. Uma ex-presidenta da associação da comunidade de Ubatumirim se apoia no fato de eles serem do lugar para defender seus direitos: "o nosso direito eles nunca vão tirar, porque nós somos nativos, tradicional, né? Nunca vão conseguir tirar nós daqui".

Por outro lado, todos os outros atores, desde a gestão até os pesquisadores, usam as categorias identitárias. A própria gestão do Parque passou a utilizar o "estatuto jurídico de tradicionais" (Simões, 2010) para poder diferenciar entre os moradores com quem seria permitido negociar e aqueles excluídos do processo. Ainda que o PESM, segundo a Lei, não possa ter moradores no seu interior, o NP tem quatro comunidades bem estabelecidas. Estas áreas são consideradas hoje como Zonas de Ocupação Temporária (ZOT) ou Zonas Histórico-Culturais Antropológicas (ZHCAn) segundo seus 
moradores tenham o estatuto jurídico de tradicionais ou não (IFSP, 2006; Simões, 2010). Como já foi indicado, é devido a esta categorização que têm aparecido algumas novas clivagens internas às comunidades e alguns moradores considerados "não tradicionais" têm sido excluídos de alguns direitos, como o acesso à energia elétrica.

É importante não esquecer, então, que quando é criada uma categoria também se está criando uma categoria oposta. Dito de outra forma, quando se diz para um tipo de pessoas que foi decidido quem elas são, que são "tradicionais", por exemplo, se deve levar em consideração que, ao mesmo tempo, se está definindo aquilo que o restante não é. O nível de arbitrariedade na escolha de quem pertence à categoria pode ser discutido, mas é inquestionável a existência dessa arbitrariedade ${ }^{7}$. Basear a discussão do território, do acesso aos recursos naturais e, inclusive, aos serviços básicos nessas categorias pode ser um tanto polêmico.

As categorias identitárias são o pilar do ordenamento do território dentro do Parque. Assim, no plano de manejo, as ZHCAn e as ZOT não são realmente áreas, mas pessoas. E são pessoas porque estão definidas a partir de quem habita nelas, se esses moradores são considerados tradicionais ou não. O mapa do Plano de Manejo, onde as ZOT e as ZHCAn estão desenhadas, é uma representação da localização dos moradores com um e outro estatuto jurídico. Entretanto, um morador com o estatuto jurídico de tradicional pode ser vizinho de um que não tenha esse mesmo estatuto. Assim, a área usada pelo primeiro se encaixaria dentro de uma ZHCAn e a do seu vizinho dentro de uma ZOT.

A discussão que se propicia a partir disso teria como pergunta básica: em que se deve basear a incorporação dos moradores na gestão e no uso dos recursos do Parque? Em uma questão moral, histórica, identitária ou pragmática? Talvez a questão identitária reproduza as clivagens já existentes e se torne uma discussão que não tem, pelas suas próprias características, muita capacidade para evoluir e criar espaços nos quais se discuta o uso dos recursos naturais e o acesso à terra de uma forma mais abrangente.

Por outro lado, poderia parecer que, se analisarmos o discurso dos moradores desde a perspectiva da identidade e da cultura, na realidade estaríamos enxergando só a ponta de um iceberg, que ocultaria outra série de interesses entrelaçados, principalmente, à propriedade da terra e ao direito ao trabalho. Aparentemente, as condições e as características desta arena fazem com que seja mais fácil dialogar, negociar e lutar baseados na identidade do que em termos de propriedade. Os próprios técnicos têm dificuldade em assumir que existe uma perspectiva materialista no discurso dos moradores ditos tradicionais. Ao que parece, esses técnicos creem que um discurso culturalista é mais legítimo, mais honrado e mais justo. Em outras palavras, a arena favorece a luta e as ações dos moradores baseadas nas reivindicações identitárias em detrimento das de propriedade, das econômicas e das relacionadas ao trabalho.

Assim, o uso da estratégia identitária evoluiu para uma estratégia de propriedade coletiva da terra (os territórios quilombolas, por exemplo). Esta estratégia foi o que as circunstâncias lhes ofereceram, devido à conjuntura política e a alguns atores-chave que se tornaram aliados. Nesse contexto, existe um confronto entre a propriedade coletiva e a propriedade individual da terra. Provavelmente, as estratégias

\footnotetext{
E nos referimos a esta arbitrariedade levando também em consideração que existem normas legais por trás dessas definições. A Convenção 169 da OIT ou o Artigo n ${ }^{\circ} 68$ das Disposições Constitucionais Transitórias da Constituição Federal, por exemplo. A gestão do Parque, ou quaisquer órgãos vão decidir se aqueles grupos sociais, ou aqueles indivíduos, são de fato "tradicionais".
} 
relacionadas à propriedade individual da terra teriam sido as preferidas, se elas tivessem sido possíveis. A estratégia da propriedade coletiva tem originado algumas clivagens no interior das comunidades. A mais clara delas é a separação da comunidade Cambury, onde só a metade da comunidade fazia parte do Quilombo reconhecido, pelo menos até o fechamento desta pesquisa. Aparentemente, essa divisão pareceria ocasionada pelos desacordos a respeito das questões identitárias (como os moradores que não se reconhecem quilombolas) ${ }^{8}$, mas, muito provavelmente, ou na maioria dos casos, esse conflito esteve relacionado à forma de encarar a propriedade da terra. "Se um dia eu quero ir embora, ou se meu filho quer vender, ou fazer casa, não pode", disse um morador da comunidade que não pertence ao quilombo.

\section{As posições em confronto sobre o acesso à terra e o uso dos recursos naturais}

Neste momento, a luta pelo uso direto dos recursos naturais é mais difícil que a da permanência no interior do PESM. Os biólogos da conservação e os gestores das áreas protegidas têm mais dificuldade em fazer concessões e de negociar regras destinadas a esse tipo de uso, em detrimento dos esforços feitos em relação aos usos indiretos dos recursos naturais. Novamente, a questão da tradicionalidade vinculada à identidade parece ser $o$ eixo que guia algumas opiniões. Quando se fala em agricultura, caça, ou outro tipo de uso direto da floresta, a luta dos moradores é mais intensa, e seus aliados tenderiam a diminuir. Muitos pesquisadores ou membros de ONG dão prioridade aos usos indiretos que, segundo eles, iriam diminuir o conflito com a gestão.
Uma das lideranças da comunidade Sertão da Fazenda disse: "Eles restauraram a Casa da Farinha [da comunidade] [...] dizendo que [...] ia gerar renda pra comunidade. [...] Ai, restauraram e tiraram o direito de plantar! E aí, virou o quê? Virou pra uso turístico, tirar foto, porque dai, se as pessoas não podem plantar sua mandioca, vão fazer sua farinha como? De areia de praia?". Uma liderança antiga da mesma comunidade reforçou esta situação quando disse: "Eu sou obrigado a conviver com o turismo porque acabou a pesca artesanal que o pessoal fazia, a agricultura que ainda precisa. [...] Na minha opinião eu dependo das pessoas de fora". Os moradores desta comunidade, assim como das outras três comunidades do $\mathrm{NP}$, têm tido que adequar-se, em maior ou menor grau, aos usos indiretos dos recursos naturais, como o turismo, para poder continuar trabalhando.

É importante, então, refletir se todos moradores de Picinguaba vão poder sobreviver e cobrir suas necessidades a partir dos usos indiretos. Os moradores também se definem a si mesmos a partir de suas atividades. Não só lutam pelo direito de vender a banana, brigam pelo direito de serem agricultores de banana, de continuar fazendo o que eles faziam antes, pelo direito ao trabalho. Como já foi descrito, a chegada de pessoas de fora à região de Picinguaba produziu uma transformação social. O turismo, tanto de segunda residência quanto de veraneio, proporcionou alternativas aos moradores, que viram restritos os usos diretos dos recursos naturais devido à chegada do Parque, às suas regras e à fiscalização.

Uma liderança da comunidade de Ubatumirim disse: "Quem tem dificuldade em fazer uma roça pega serviço com o turista. O trabalho com os turistas que têm terrenos na comunidade se tornou,

8 Ver o Relatório técnico-científico sobre os remanescentes da Comunidade do Quilombo de Cambury realizado e publicado pelo FITESP (2002). 
então, uma alternativa, principalmente na Vila de Picinguaba e em Ubatumirim". Esta liderança continuou dizendo: "E têm lá o seu ganha-pão, e já vão deixando de lado a cultura de plantio e tal. Uma, porque não pode, tá sujeito a ir preso, e outra porque vê uma situação mais fácil".

Entretanto, a relação entre os moradores e os "de fora" que compraram terrenos nas comunidades não só é assimétrica desde o ponto de vista no qual os primeiros acabaram sendo os empregados dos segundos. As posições que ocupam um e outro reproduzem essas assimetrias de muitas outras formas. Uma liderança da Vila de Picinguaba reclamou dessa situação: "Quem tem que ganhar o dinheiro somos nós. É nós que dependemos do que nós ganhamos 365 dias do ano [...]. Só que não acontece isso. O rico que vem de lá pra cá, ele já tem dinheiro, porque se não tivesse dinheiro, não compraria uma casa em um lugar desse".

Por outro lado, alguns outros usos indiretos dos recursos são propostos pela gestão, como a administração do estacionamento e da lanchonete próxima ao Centro de Visitantes do Núcleo Picinguaba, e outros relacionados ao turismo. Mas, destas alternativas econômicas poderá manter-se uma porção considerável dos moradores da comunidade do Sertão da Fazenda, que é a beneficiária? Um membro da gestão do Parque disse: "As comunidades estão indo buscar [alternativas econômicas] e tudo dentro do correto. Eu vejo muito auxílio do Parque para a comunidade quilombola". O "correto" corresponderia à posição da gestão, mas, muito provavelmente não às posições e aos objetivos dos moradores.

Um membro da gestão do Parque opinou sobre a relação dos moradores com a gestão: "[É] uma divisão [...]. Morador tradicional é caiçara, é quilombola. Já estava aqui antes do Parque. Mas, há pessoas que estavam aqui antes que não têm nada a ver com tradicional'. Mas, a que estaria relacionada essa tradicionalidade? "A tradicionalidade é prática. Está na cara quem é", respondeu. Entretanto, se a tradicionalidade estiver relacionada à prática, e esse for o parâmetro seguido para garantir o uso dos recursos, o que acontece com moradores que não são nascidos na região, mas que têm muito tempo morando lá? Tradicional poderia ser alguém que está "só" 20 anos aqui? "Não. Pode ser considerado local, mas ele não é tradicional. Tradicional está diretamente relacionado ao lugar onde ele vive. Aí, o negócio começa a ficar complexo", respondeu, já colocando um grau maior de complexidade na questão da tradicionalidade.

Então, há comunidades "mais tradicionais" que outras? Indivíduos "mais tradicionais" que outros? Como a gestão poderia administrar essas diferenças no que se refere ao uso dos recursos naturais baseada na identidade? Sendo assim, quem teria o poder para decidir essa tradicionalidade atribuída aos moradores? "Ninguém tem poder. Eles têm que se reconhecer [...]. É que se você analisa minuciosamente, tem moradores tradicionais [...]. É difícil, mas você sabe quem é", disse o mesmo membro da gestão. A pergunta que surge aqui seria: a tradicionalidade que, segundo algumas posições, deve ser usada para negociar o uso dos recursos naturais está baseada nas práticas ou na origem de quem executa as práticas?

Existem algumas dificuldades, então, sobre a questão identitária relacionada ao uso dos recursos naturais. Se os moradores ditos tradicionais são os que teriam direito a permanecer na área e a certo grau de uso dos recursos, e, por outro lado, aquela tradicionalidade é valiosa para a gestão devido a que produz práticas mais acordes com a conservação, por que algumas dessas práticas têm tanta dificuldade para serem realizadas? Se a tradicionalidade garante a conservação, por que não são aceitas $a$ 
priori todas as práticas tradicionais? E se um morador deixa de ser considerado tradicional porque já não é "conservacionista", por que um morador que não era considerado tradicional não passa a sê-lo logo ao se tornar "conservacionista"?

Como já foi discutido, a questão da terra, o acesso, a posse, a propriedade, são assuntos de muita importância para os moradores de Picinguaba devido ao histórico de venda de terras para pessoas "de fora", às ameaças da especulação imobiliária no litoral paulista e ao próprio estabelecimento do Parque, o que poderia ter influenciado a forma como se relacionam entre si e com seus territórios. Isto significa que os moradores de Picinguaba vêm há algumas décadas sentindo-se ameaçados por atores com maiores recursos de poder no que diz respeito não só à propriedade da terra que os moradores consideram própria, mas, inclusive ao direito de permanecer nela e continuar realizando as atividades produtivas das quais dependem. $\mathrm{O}$ uso da questão identitária também é um eixo nesta luta pelo direito à cidadania plena, à moradia e ao trabalho. Um membro de uma ONG da região disse: "Eu acho que a discussão [em Picinguaba] sempre foi de território, acho que em poucos momentos passou pelo uso dos recursos".

Sobre o futuro dos moradores com respeito à questão da terra, outro membro de uma ONG da região disse: "Eu não sei. Às vezes tenho a impressão que nunca vai se resolver". Ele mesmo é claro quanto a sua posição crítica à gestão do NP sobre os processos relacionados ao uso dos recursos e ao acesso à terra: "Foi criado o Plano de Uso Tradicional, e assim, o Parque veio com essa proposta de participativo. Na verdade, foi goela abaixo, foi nada participativo". Mais um membro de uma ONG também foi crítico à gestão quando indicou que "infelizmente, quem está na gestão dessas unidades de conservação são técnicos de escritório que não têm a visão prática".

Em discordância com esta posição, um membro da gestão disse que a criação das ZHCAn " $f o i$ um avanço imenso [...]. Se não houvesse o Plano de Uso Tradicional, a guerra seria muito grande. Para a gestão, foi um passo enorme". Nesse mesmo sentido, um morador da comunidade Cambury descreveu sua posição sobre o Plano de Uso Tradicional e a relação dele com o acesso aos serviços básicos na comunidade, como a luz elétrica, e com o uso direto dos recursos naturais: "O ITESP ${ }^{9}$ veio e disse [que] não era para ter assinado isso aí. Era obrigatório a luz ir pra vocês. Não tinha essa de eles embargar a luz pra vocês. Não era pra vocês assinarem esse Plano de Manejo. Fizeram a maior bobeira ter assinado esse Plano de Manejo".

Como disse o membro da gestão linhas acima, para os moradores da comunidade é muito difícil aceitar e concordar com a dependência que têm em relação à gestão do Parque. Por outro lado, a institucionalidade relacionada a uma UC de Proteção Integral, como é o caso do PESM, poderia oferecer melhores condições? Estas duas posições em confronto: por um lado, a dos moradores que precisam do uso dos recursos; e, por outro, a da gestão que precisa adequar-se às regras e à legislação, produzem conflitos que são muito complicados de administrar. Existe, da mesma forma, uma falta de sincronia entre as exigências, de um lado, e as possíveis respostas, do outro.

Tendo como base a desconfiança no Estado, que foi construída a partir da história, os acordos e as negociações se tornam muito difíceis. Sempre permanece a ideia de que as propostas são, na realidade, novas formas de engano. Uma liderança

\footnotetext{
9 Fundação Instituto de Terras do Estado de São Paulo.
} 
local disse, nesse sentido, que "é uma cultura de desconfiança que está sendo cultivada [...]. Então, como o Estado vai dar crédito necessário para acreditar nele?". Reconstruir a relação entre a gestão e os moradores não foi nem será uma tarefa fácil. O olhar mútuo de desconfiança permanece em Picinguaba apesar dos esforços da gestão e de seus parceiros.

Claramente, os processos de construção de espaços de confiança e de negociação não são lineares. Diversos acontecimentos podem produzir novos conflitos, ou reformular os já existentes, fazendo com que as negociações se trunquem, se tornem mais difíceis, ou, inclusive, que desapareçam temporariamente. A construção da confiança entre os atores é frágil no Núcleo Picinguaba. Não só os atores têm ideias preconcebidas e desconfiam dos outros, mas a confiança conquistada pode desaparecer facilmente depois de algumas ações pontuais. Obviamente, essas ações pontuais no nível local podem estar influenciadas por decisões em níveis mais altos da arena, ou estar influenciadas pelas características particulares dos atores. Essa teia de relações continua permeada por essa história, tornando instáveis os espaços de negociação. O membro de uma ONG que faz pesquisa na região disse: "Para trabalhar com a comunidade, a primeira coisa é estabelecer o laço de confiança. E eles têm todos os motivos do mundo para ter essa desconfiança".

A confiança entre os atores não tem sido favorecida ao longo do processo histórico em Picinguaba e isso fica claro nos depoimentos apresentados. As diversas posições existentes, que nem sempre podem ser divididas segundo o "tipo de ator" (gestores, moradores, pesquisadores), assim como os históricos e perspectivas diferentes, ocasionam que se vejam com desconfiança e que a negociação não seja simples. Mas, então, levando em consideração tudo o dito, há bandidos na Serra do Mar?

\section{Conclusão: sim, há bandidos na Serra do Mar}

Este texto começou com uma pergunta que quis ser retórica: bandidos na Serra do Mar? Entretanto, a pesquisa que deu origem ao texto começou muito antes da formulação dessa pergunta, que foi produto de um aprendizado, de uma reflexão vinda do campo e da experiência prévia. Ela quis ser retórica porque não pretendia ser respondida, sua resposta estava dada. Pretendia-se explicá-la, usá-la como ponto de partida para contar a história e descrever o conflito, a ação dos atores, suas estratégias, suas lutas e como isso influenciava nos processos sociais associados à conservação da biodiversidade. A motivação dessa pergunta proveio dos depoimentos dos moradores do Núcleo Picinguaba, de como eles se sentiram e ainda se sentem a respeito das ações do Parque, da perda da sua condição de trabalhadores, das restrições no uso dos recursos naturais e, claro, no acesso e na propriedade da terra. Eles colocaram essas palavras para se referir a si mesmos porque a história os tinha colocado nesse lugar. "Viramos bandidos", "somos trabalhadores bandidos", disseram. Dessa forma, foi se construindo o argumento para tentar demonstrar que a pergunta era mesmo retórica: será que eles são mesmo uns bandidos? Obviamente, não. Contudo, a trajetória desta pesquisa nos levou a perceber que, na realidade, cada um dos atores envolvidos neste conflito e participantes desta arena acha que sim, que há bandidos na Serra do Mar. Cada um deles tem seu(s) próprio(s) bandido(s) e suas próprias razões para tê-lo(s).

Olhar a realidade do Núcleo Picinguaba desde diferentes pontos de vista, desde o dos moradores, o dos gestores, o dos pesquisadores e o dos membros de ONGs, fez com que pudéssemos ter acesso às 
posições de cada um, porque a realidade não é uma só. Se quem escrevesse este texto fosse um morador originário, a palavra "bandidos", contida no título, provavelmente faria referência aos gestores (ao "Parque", ao "meio ambiente"). E esse hipotético autor também poderia sentir que essa pergunta é retórica, porque, segundo suas perspectivas e sua posição na história, a resposta também poderia ser óbvia. Foram os gestores os que apareceram para privá-los das atividades que exerciam antes. Os bandidos, então, seriam eles. Dessa forma, se pode perceber que essa pergunta é pertinente para qualquer um dos atores da arena. De qualquer maneira, tentar olhar o conflito a partir das diferentes perspectivas (em confronto) proporciona uma visão privilegiada, não isenta de obliquidades, sobre o que acontece e aconteceu em Picinguaba. Reconhecermo-nos como atores que carregam uma bagagem é fundamental.

Sendo assim, a trajetória desta pesquisa nos leva a perceber que, sim, há bandidos na Serra do Mar. Cada um dos atores poderia enxergar diversos bandidos ao longo da história. Os gestores e os encarregados da fiscalização, e, muito mais no começo do conflito pelo estabelecimento do Parque, poderiam ter achado e tratado os moradores originários como bandidos, como aqueles que "destroem" o lugar que eles são chamados a proteger. Mas, estes moradores originários também considerariam os moradores "de fora" e os turistas como bandidos, aqueles que chegaram para enganá-los, que hoje lucram com o que tiraram deles e que não os respeitam. Para os gestores, um morador "de fora" poderia ser mais bandido que um morador originário. Os moradores achariam que a gestão do Parque (o "meio ambiente") também é bandida. São esses os bandidos que tiraram seus direitos, os que derrubaram suas casas, os que estão aí para enganá-los, para fazer difícil sua vida, para não deixá-los trabalhar, melhorar de vida. Os moradores "de fora" veriam os gestores como os bandidos que querem negar seus direitos adquiridos. Alguns membros de ONGs mais favoráveis aos moradores originários poderiam achar que a gestão do Parque é bandida também, bandida porque não permite que esses grupos humanos continuem morando do jeito que moravam antes da implementação da UC e melhorem sua qualidade de vida. Alguns pesquisadores poderiam achar bandidos os moradores que caçam para comer, que derrubam a mata para plantar; assim como alguns moradores poderiam achar bandidos os pesquisadores que chegam, coletam dados, vão embora e nunca mais voltam para dar satisfação. Em definitivo, todos os atores que de alguma forma estão vinculados ao NP e que participam nesta arena poderiam ser um pouco bandidos para alguns dos outros atores. Sempre, e desde qualquer um dos olhares, poderia ter um bandido.

Então, esse sinal de interrogação que construía a pergunta retórica no começo deste texto tornou-se uma afirmação. Sim, há bandidos na Serra do Mar, e os bandidos poderiam ser todos e cada um. Talvez todos os usuários dos recursos de uso comum que, neste caso, seria o território do Parque (onde acontecem e são disputados os usos em pesquisa, os usos diretos, a conservação, a agricultura, a caça), acham em menor ou maior grau que os outros são bandidos. Isso levaria a que um fator determinante para o manejo do conflito e para que os acordos possam ser alcançados não aconteça, pelo menos não plenamente. Isso que falta é a confiança. Sem confiança nas pessoas com as quais temos acordos, eles, se chegarem a existir, não têm um futuro muito promissor.

Talvez, em lugar de confiança, o que existe é certa tolerância. A tolerância faz com que alguns avanços possam acontecer e que a arena não seja sempre um espaço de conflito direto, de enfrenta- 
mentos constantes que só desgastam os atores e suas relações. Algum tipo de trégua tem que existir porque os atores precisam realizar suas atividades, viver. Essa tolerância pode ter contribuído à construção e à manutenção de espaços de discussão, à produção de alguns avanços e a períodos de certa tranquilidade. Mas, a tolerância é muito frágil e muito instável. Espaços nos quais se constrói uma verdadeira confiança são necessários se pretende-se que todos os atores negociem, cooperem e se organizem de formas mais democráticas, produtivas e benéficas para todos. As regras estabelecidas entre todos deveriam ser criadas e discutidas em espaços de confiança, mas, o processo de construção desses espaços também precisa de confiança para acontecer. As armas têm que ficar do lado de fora da sala onde se reúnem para discutir e definir as regras, e, claro, as sanções impostas para aqueles que não as cumpram $^{10}$.

Uma das dificuldades no estabelecimento das regras e das sanções é que, facilmente, se pode cair em falsos espaços democráticos. Talvez o importante seja que cada ator saiba que todos os outros também têm algo em jogo, algo a perder se não forem respeitadas as regras, assim como deveriam estar dispostos a fazer algumas concessões. É aqui que os gestores do Parque não aparecem com o mesmo poder que os usuários diretos dos recursos. Da mesma forma como se deveriam criar sanções para os usuários que não cumpram as regras definidas democraticamente, não se deveria falar também em sanções para os gestores que não respeitem suas atribuições? E para os pesquisadores? Poderíamos pensar em mecanismos participativos de controle local nesse sentido?
Entretanto, e como sugerem Ferreira et al. (2001), é importante ressaltar que o estabelecimento de regras não vai acabar com as assimetrias de poder existentes entre os atores da(s) arena(s). Existem conflitos que são estruturais, que não vão ser resolvidos só pelo estabelecimento de regras, ainda que sejam construídas de forma participativa. Inclusive, algumas dessas assimetrias provavelmente nunca vão mudar. $\mathrm{O}$ que um pescador tem em jogo quando se discute a conservação de uma espécie de peixe da qual ele depende é equivalente ao que tem em jogo um ictiólogo? Essa diferença entre o que cada um tem em jogo é estruturante.

Existe um confronto entre o que cada ator considera que está em jogo, mas também existe um confronto de perspectivas históricas, de posições nessa história que estão determinadas pelo lugar desde onde cada tipo de ator foi testemunha e/ou protagonista dela. Não é a mesma coisa ser filho de um agricultor ou de um pescador de Picinguaba, e conhecer a história da região a partir dessa vivência, que ser um pesquisador ou um gestor com outro tipo de visão e percepção dessa mesma história. Um morador de uma UC pode não compreender ou não concordar com a visão dos gestores devido à posição diferente desde onde cada um deles vê o que acontece e aconteceu. É possível que os gestores e os pesquisadores vejam a particularidade de Picinguaba desde um contexto bem mais amplo, desde aquele emblemático $7 \%$ de Mata Atlântica remanescente; já os moradores originários vão ver essa mesma região como seu lugar de trabalho, de moradia, de história familiar. Eles podem não achar justas as restrições de uso e permanência a partir dessa grande diferença de perspectivas. Eles

\footnotetext{
10 Segundo Ostrom (2002), é importante que a organização que tem como objetivo a criação de regras que especifiquem direitos e deveres crie um bem público para todos aqueles que estão envolvidos. Ostrom (1990) define, no seu princípio 2, que o processo de governança dos recursos de uso comum deve envolver a congruência entre as regras que dão benefícios e as regras que dão custos. No princípio 3 , se refere às sanções graduais para os usuários que não cumpram as regras.
} 
podem não achar justo que alguém de fora lhes diga como devem agir e, inclusive, o que devem ser e permanecer sendo.

Em resumo, a participação de todos os atores no estabelecimento das regras não será suficiente para solucionar os conflitos relacionados ao uso dos recursos naturais. Deveria acontecer dessa forma, mas não será suficiente. Esta realidade polifônica está relacionada às diversas posições em confronto e aos usos múltiplos dos recursos naturais e precisa de uma análise também diversa, desde os diferentes olhares e levando em consideração os vários níveis da arena. Por outro lado, a gestão compartilhada dos recursos naturais deveria incluir, também, a democratização dos sistemas coercitivos em direção a todos os atores e não só aos moradores e usuários diretos.

$\mathrm{Na}$ análise particular feita nesta pesquisa, não é possível fugir de uma discussão que tem como pano de fundo a justiça e a cidadania plena, que é o que finalmente exigem os moradores de Picinguaba, talvez não com essas palavras, mas, nas entrelinhas de seus depoimentos, essa exigência fica muito clara. Como dizem Esterci \& Schweickardt (2010), os agentes públicos negociam e dão novas formas à intervenção do Estado consolidando seu poder tutelar sobre os grupos sociais que habitam no interior de UCs. Dessa forma, deveríamos refletir se queremos que o Estado continue tutelando os moradores dessas áreas, definindo como eles devem agir para continuar tendo ou, melhor, para voltar a ter alguns dos seus direitos garantidos. Ou, pelo contrário, um Estado que promova sua autodeterminação e seu empoderamento como grupos humanos autossuficientes que possam discutir, junto aos outros atores, o uso dos recursos naturais e sua conservação.

É importante enfatizar que, quando criticamos a consolidação do poder tutelar do Estado frente às populações que habitam no interior de UCs, não pretendemos negar as assimetrias existentes entre os diversos atores, como já foi dito em várias oportunidades. É importante ter cuidado para não cair em falsos espaços democráticos onde, sob a premissa da igualdade, não se levem em consideração as assimetrias e a história. Nesses espaços de discussão e negociação, o recomendável seria tratar igual aos iguais e diferente aos diferentes, promovendo assim seu empoderamento como atores. Entretanto, tampouco queremos dizer que os moradores deveriam ser sempre tratados como os atores hegemônicos porque, na maioria dos casos, eles não estarão sós. Todos os atores procuram alcançar seus próprios objetivos e negociam com os outros tendo como base a conjuntura e os processos de retroalimentação.

Desta forma, sugerimos que se deveriam fazer os esforços necessários para tirar o centro da discussão da questão identitária e colocá-lo nos processos de definição, estabelecimento e monitoramento de acordos e regras sobre o uso dos recursos naturais e do território de forma participativa. Vários autores já manifestaram que a ideia de que o perfil conservacionista não está necessariamente associado à etnicidade (Lima \& Pozzobon, 2005; Ferreira et al., 2007; Castro et al., 2008; Mendes \& Ferreira, 2009). Se deveria, então, colocar o foco do debate nos tipos de uso dos recursos naturais e não nos tipos de ator. Atualmente, os moradores de Picinguaba vinculam estas regras às "proibições", às autorizações que precisam pedir para arrumar suas casas e às multas que têm que pagar por "trabalhar". Estas regras estariam vinculadas, segundo os moradores, sempre a um "não", a uma negação que não tem negociação, nem antes de ser estabelecida, nem depois. Essas negações tirariam toda possibilidade de abrir espaços de diálogo entre os usuários, os gestores e o restante de atores. Estas negações, ademais, reforçariam a ideia de que o 
Parque chegou para prejudicar e que age sobre a vida dos moradores como um ente poderoso que decide pela vida, pelo trabalho e pelo futuro dos moradores.

O importante seria definir essas regras e esses acordos criando mecanismos para que sejam estabelecidos de forma democrática e participativa e que, por sua vez, outorguem as condições para que possam ser cumpridos por todos os atores, independentemente da sua origem identitária e levando em consideração o contexto de desconfiança mútua. Esta definição sempre será relativa ao tipo de ator encarregado de fazê-la, a suas perspectivas, aos seus interesses e a sua posição na arena, e nunca estará livre de arbitrariedades. O estabelecimento de sansões para os usuários dos recursos naturais deveria ser igualmente discutido e sob condições similares às nomeadas acima. E, quando nos referimos aos usuários, o fazemos no sentido amplo. Isto é, levando em consideração os usos múltiplos, desde os mais diretos até os mais indiretos.

Então, poderíamos falar mais apropriadamente na diferença no "como", como esse objetivo da conservação pretende ser alcançado, e até na mesma definição de conservação que tem cada um dos atores da arena. Seja como for, tanto os gestores destas áreas quanto os pesquisadores e os membros de ONGs que atuam nelas poderíamos fazer esforços para mudar a percepção da conservação como antagônica ao uso dos recursos e à melhoria da qualidade de vida dos moradores.

Finalmente, podemos dizer que seria recomendável que acontecesse um processo de recategorização das áreas ocupadas no interior do NP que não estejam reconhecidas como Territórios
Quilombolas. Dessa forma, estas áreas não ficariam desprotegidas institucionalmente e vulneráveis às ameaças relacionadas, sobretudo, à especulação imobiliária. Por outro lado, no caso das comunidades que tenham conseguido certa independência da gestão do Parque por meio do reconhecimento quilombola, tudo parece indicar que seus moradores não trocariam essa nova institucionalidade por outra UC, ainda que seja de Uso Sustentável. Nesse caso, elas poderiam ser incorporadas ao manejo participativo dos recursos naturais devido a sua condição de estarem localizadas no entorno do Parque e da(s) nova(s) área(s) a ser(em) criada(s), levando em consideração critérios de zoneamento.

Reconhecer que a realidade polifônica do Núcleo Picinguaba carrega uma história acidentada que leva a que todos os atores da arena se percebam, em maior ou menor grau, como "bandidos" e cujas posições estão em confronto é de suma importância para regular os conflitos sobre o uso dos recursos naturais e o acesso à terra na área. Levar em consideração a multiplicidade destes usos, assim como ser conscientes de que as características estruturantes da arena influenciam o que cada um dos atores tem em jogo, também é determinante para tentar diminuir as assimetrias entre eles e, assim, poder discutir democraticamente as regras de manejo que sejam benéficas para todos. Os arranjos institucionais surgidos ao longo deste processo, ainda que transitórios, estão sendo permanentemente testados como em um laboratório para criar novas instituições. Aqueles que funcionarem e mostrarem consistência para regular estes conflitos poderão permanecer e moldarão nossa sociedade no que respeita às dimensões humanas da conservação da biodiversidade. 


\section{Referências}

Adams, C. As populações caiçaras e o mito do bom selvagem: a necessidade de uma nova abordagem interdisciplinar. Revista de Antropologia, 43(1), 2000.

Almeida, M. W. B. O Estatuto da Terra e as Reservas Extrativistas. Revista da Associação Brasileira de Reforma Agrária-ABRA, 25(1), 153-167, 1995.

Almeida, M. W. B.; Carneiro da Cunha, M. Global Environmental Changes and Traditional People. In: Hogan, D. J.; Tolmasquim, M. T. (Orgs.). Global Environmental Changes: Brazilian Perspective. Rio de Janeiro: Academia Brasileira de Ciências, 2001.

Arruda, R. "Populações tradicionais" e a proteção dos recursos naturais em unidades de conservação. Ambiente \& Sociedade, 2(5), 1999.

Barretto Filho, H. T. Traditional Peoples: Introduction to the Political Ecology Critique of a Notion. In: C. Adams et al. (Eds.). Amazon Peasant Societies in a Changing Environment. Science + Business Media B.V. 2009. p. 95-129.

Boyer, V. Énoncer une “identité" pour sortir de l'invisibilité. La circulation des populations entre les catégories légales (Brésil). L'Homme, 214, 2015.

Brasil. Lei $n^{\circ}$ 9.985, de 18 de julho de 2000. Cria o Sistema Nacional de Unidades de Conservação da Natureza (SNUC). Brasília, 2000.

Brasil. Decreto $n^{\circ} 6.040$, de 7 de fevereiro de 2007. Institui a Política Nacional de Desenvolvimento Sustentável dos Povos e Comunidades Tradicionais. Brasília, 2007.

Campos, S. V. Jaú em jogo: mudanças sociais e conservação ambiental no Parque Nacional do Jaú (AM). Campinas, SP, Tese (Doutorado em Ciências Sociais) - UNICAMP, 2006.

Calvimontes, J. Bandidos na serra do mar? Conflitos, estratégias e usos múltiplos dos recursos naturais na mata atlântica. Campinas, SP, Tese (Doutorado em Ambiente e Sociedade) - UNICAMP. 2013.

Carneiro da Cunha, M. Cultura com aspas e outros ensaios. São Paulo: Cosac \& Naify. 2009.

Carneiro da Cunha, M.; Almeida, M. W. B. Indigenous People, Traditional People, and Conservation in the Amazon.
Daedalus, 129(2), 315-338, 2000. Brazil: The Burden of the past; the Promise of the Future (Spring, 2000).

Castro, E. Território, biodiversidade e saberes de populações tradicionais. In: Diegues, A. C. (Org.). Etnoconservação: novos rumos para a proteção da natureza nos trópicos. São Paulo: Annablume, 2000. p. 165-182.

Castro, F.; Siqueira, A. D.; Brondízio, E. S.; Ferreira, L.C. Use and misuse of the concepts of tradition and property rights in the conservation of natural resources in the Atlantic Forest (Brazil). In: Krishna, S.; Acharya, S. (Eds.). Common property resources. Concepts ans country experiences. The ICFAI University Press, 2008. p. 41-62.

Colchester, M. Resgatando a natureza: comunidades tradicionais e Áreas Protegidas. In: Diegues, A. C. (Org.). Etnoconservação: novos rumos para a proteção da natureza nos trópicos. São Paulo: Annablume, 2000. p. 225-256.

Coleman, J. S. Foundations of Social Theory. Cambridge: Harvard University Press, 1994.

Diegues, A.C. Etnoconservação da natureza: enfoques alternativos. In: Diegues, A. C. (Org.). Etnoconservação: novos rumos para a proteção da natureza nos trópicos. São Paulo: Annablume, 2000. p. 1-46.

Diegues, A. C. O mito moderno da natureza intocada. São Paulo: Hucitec, 2001.

Diegues, A. C.; Arruda, R. S. V. Saberes tradicionais e biodiversidade no Brasil. Brasília: Ministério de Meio Ambiente. 2001.

Diegues, A. C.; Arruda, R. S. V.; Silva, V. C. F.; Figols, F. A. V.; Andrade, D. (Org.). Os saberes tradicionais e a biodiversidade no Brasil. São Paulo: MMA/COBIO/ NUPAUB/USP, 2000.

Esterci, N.; Schweickardt, K. H. S. C. Territórios amazônicos de reforma agrária e de conservação da natureza. Boletim do Museu Paraense Emílio Goeldi. Ciências Humanas, 5(1), 59-77, 2010.

Ferreira, L. C. A floresta intransitiva: conflitos e negociações na Mata Atlântica, SP. Campinas, SP, Tese (Doutorado em Ciências Sociais) - UNICAMP, 1996. 
Ferreira, L. C. Conflitos sociais e uso dos recursos naturais: breves comentários sobre modelos teóricos e linhas de pesquisa. Política e Sociedade, 7, 2005.

Ferreira, L. C. A equação dinâmica entre conflitos sociais, recursos naturais e desastres ambientais: o estado da arte e uma proposta teórica. In: Anais do VI Encontro Nacional ANPPAS. Belém, Pará. 18-21 de setembro de 2012.

Ferreira, L. C.; Sivieiro, S. O.; Campos, S. V.; Silveira, P. C. B; Oliveira, V. G.; Mendes, A. B. V.; Pinto, A. O. Conflitos sociais em áreas protegidas no Brasil: moradores, instituições e ONGs no Vale do Ribeira e Litoral Sul, SP. Revista Ideias, Campinas, 8(2), 115-149, 2001.

Ferreira, L. C.; Campos, S. V; Creado, E.; Mendes, A. B.; Caropreso, C. Encontro das águas: dinâmicas sociais e biodiversidade na Amazônia Brasileira. Teoria \& Pesquisa 50, 16(1), 15-37, 2007.

Ferreira, L. C.; Di Giulio, G. M.; Simões, E.; Viglio, J. E.; Calvimontes, J.; Araos, F.; Mello, A. Y. I.; Manfredo, M. T. Feital, M. S.; Thiago, J. P.; Queiroz, J. F. Conflitos entre expansão urbana e a cobertura vegetal e suas consequências para as Mudanças Ambientais Globais: um estudo no Litoral de São Paulo. In: Ferreira, L. C.; Joly, C. A. Ferreira, L. C; Carmo, R. L. (Coords.). Urban Growth, Vulnerability and Adaptation: Social and Ecological Dimensions of Climate Change on the Coast of São Paulo. (Relatório Técnico). 2012. p.157-240.

FITESP - Fundação Instituto de Terras do Estado de São Paulo. Relatório Técnico-Cientifico sobre os Remanescentes da comunidade de Quilombo de Cambury. São Paulo, 2002.

Gluckman, M. The Peace in the Feud. Past and Present, 8(1), 1-14. 1955. doi: 10.1093/past/8.1.1

Hannigan, J. Sociologia Ambiental. Petrópolis, RJ: Vozes, 2009.

IFSP - Instituto Florestal do Estado de São Paulo. Plano de Manejo do Parque Estadual da Serra do Mar. São Paulo, 2006.

Jolivet, M.-J.; Léna, P. M. Des territoires aux identités. Autrepart, 14, 5-16, 2000.

Lima, D. M.; Pozzobon, J. Amazônia socioambiental. Sustentabilidade ecológica e diversidade social. Estudos Avançados, 19(54), 45-76, 2005.
Little, P. E. Territórios sociais e povos tradicionais no Brasil: por uma Antropologia da Territorialidade. Brasília: Universidade de Brasília, 2002. (Série Antropológica)

McAdam, D.; McCarthy, J. D.; Zald, M. N. Oportunidades, estruturas de movilización y procesos enmarcadores: hacia uma perspectiva sintética y comparada de los movimientos sociales. In: McAdam, D.; McCarthy, J. D.; Zald, M. N. (Eds.). Movimientos sociales: perspectivas comparadas. Madrid, España: Ediciones Istmo, 1999.

Mendes, A. B. V. Protegendo diversidades: entre ambientes e culturas no Estado Brasileiro. Teoria e Sociedade, 19(2), 2011.

Mendes, A. B. V.; Ferreira, L. C. Conservação ambiental e direitos multiculturais: apontamentos sobre direito e ciências. UAKARI, 5(2), 2009.

Ostrom, E. Governing the commons: The evolution of institutions for collective action. Cambridge: Cambridge University Press, 1990.

Ostrom, E. Reformulando los bienes comunes. In: Smith, R. C.; Pinedo, D. (Eds.). El cuidado de los bienes comunes. Gobierno y manejo de los lagos y bosques en la Amazonía. Peru: Instituto del Bien Común, 2002.

Renn, O. The social arena concept of risk debates. In: Krimsky, S. (Ed.). Social theories of risk. Westport, Conn., 1993. p. 179-196.

Simmel, G. Sociologia. Organização de Evaristo de Moraes Filho. São Paulo: Ática, 1983.

Simões, E. O dilema das decisões sobre populações humanas em parques: jogo compartilhado entre técnicos e residentes no Núcleo Picinguaba. Campinas, Tese (Doutorado em Ambiente e Sociedade) - UNICAMP, 2010.

Touraine, A. Palavra e Sangue. Política e sociedade na América Latina. Campinas: Editora Unicamp; São Paulo: Trajetória Cultural, 1988.

Touraine, A. Os novos conflitos sociais, para evitar mal-entendidos. Lua Nova, 17, 5-18, 1989.

Touraine, A. Los movimientos sociales. Revista Colombiana de Sociología, 27, 255-278, 2006.

Vianna, L. P. De invisíveis a protagonistas: populações tradicionais e unidades de conservação. São Paulo: Annablume/Fapesp, 2008. 